\title{
Anti-Helicobacter Pylori, Anti-Thyroid Peroxidase, Anti-Thyroglobulin and Anti-Gastric Parietal Cells Antibodies in Czech Population
}

\author{
I. ŠTERZL ${ }^{1,2}$, P. HRDÁ ${ }^{1,2}$, P. MATUCHA ${ }^{1}$, J. ČEŘOVSKÁ ${ }^{1}$, V. ZAMRAZIL ${ }^{1}$ \\ ${ }^{1}$ Institute of Endocrinology, Prague and ${ }^{2}$ Institute of Immunology and Microbiology, First Faculty \\ of Medicine, Charles University and General Faculty Hospital, Prague, Czech Republic
}

Received November 12, 2007

Accepted January 28, 2008

On-line February 13, 2008

\begin{abstract}
Summary
Autoimmune thyropathies are frequently linked to many infections, such as Helicobacter pylori, which are also supposed to play a role in their pathogenesis. The aim of this study was to evaluate the relationships between thyroid and gastric autoimmunity and $H$. pylori infection on a large sample of Czech population $(n=1621)$ by monitoring the autoantibodies against thyroglobulin (anti-Tg) and thyroid peroxidase (anti-TPO) and gastric parietal cell (anti-GPC, representing thyrogastric syndrome) in correlation with antibodies against Helicobacter pylori (anti-H. pylori) of classes IgG and IgA. The interrelation between autoantibodies and $H$. pylori antibodies was assessed by H. pylori seropositivity. In H. pylori seropositive persons as compared to seronegative irrespective of age and sex, a higher occurrence of anti-TPO (10.4\% vs. $5.8 \%, \mathrm{p}=0.001)$ and antiGPC (6.1\% vs. $1.7 \%$, p<0.001) was found. Differences in antiTPO occurrence were significant in both men (7.0\% vs. $3.3 \%$, $\mathrm{p}=0.03)$ and women $(12.7 \%$ vs. $8.0 \%, p=0.02)$, differences in anti-GPC occurrence were significant only in women $(7.2 \%$ vs. $1.7 \%, p<0.001)$. Results of this study support the idea of a connection between infection of $H$. pylori and the occurrence of anti-TPO autoantibodies representing thyroid autoimmunity and gastric parietal cells autoantibodies representing the thyrogastric syndrome.
\end{abstract}

\section{Key words}

Helicobacter pylori • Thyroid peroxidase • Thyroglobulin • Gastric parietal cells $\bullet$ Antibodies

\section{Corresponding author}

I. Šterzl, Institute of Immunology and Microbiology, First Faculty of Medicine, Charles University, Prague, Studničkova 7, 12800 Prague 2, Czech Republic. E-mail: ister@If1.cuni.cz

\section{Introduction}

Autoimmune thyroiditis (AT) is one of the most frequently encountered endocrinopathies belonging to organ-specific autoimmune diseases. AT can also occur as a part of autoimmune polyglandular syndrome (APS) or of polyglandular autoimmunity activation (PAA). (Muir et al. 1995, Laureti et al. 1998). As serological markers of AT serve autoantibodies against thyroid peroxidase (anti-TPO) and against thyroglobulin (anti-Tg). Their occurrence has been reported in healthy women in the range from $9 \%$ to $26 \%$ and in healthy men in the range from $3 \%$ to $12 \%$ (Prentice et al. 1990, Vanderpump et al. 1995, Hawkins et al. 1980).

The etiological causes for autoimmune thyroiditis development are multifactorial, involving genetic predisposition (Hrdá et al. 2004, Todd et al. 1988) and external factors, most common being infections, such as Yersinia enterocolitica (Bech et al. 1977, Bech et al. 1974) and Helicobacter pylori (de Luis et al. 1998, Figura et al. 1999). H. pylori causes chronic, usually lifetime infection and is associated with a wide spectrum of other clinical diseases, ranging from peptic ulcer disease to gastric adenocarcinoma and mucosaassociated lymphoid tissue (MALT) lymphoma (Suerbaum and Michetti 2002) and also with many extragastroduodenal diseases: cardiovascular diseases, respiratory tract diseases, growth retardation, cerebrovascular diseases, headache and migraine, Raynaud's syndrome and with organ specific autoimmune diseases (autoimmune thyropathies, diabetes mellitus), systemic autoimmune diseases (Tsang and Lam 1999, Figura et al. 1999). In patients with autoimmune 
thyropathies an increased prevalence of $H$. pylori has been found (de Luis et al. 1998, Figura et al. 1999). Bertalot et al. (2004) reported a decrease in anti-thyroid autoantibodies after eradication of $H$. pylori infection.

Reports about $H$. pylori infection indicate higher infection rates (about $90 \%$ during adulthood) in developing countries (Bardhan 1997), while infection rates in developed countries were about $60 \%$ in higher age groups (Frenck and Clemens 2003). The World Health Organization estimates show that approximately $50 \%$ of the world's populations are infected with H. pylori, however, the majority of infected subjects develop no clinical symptoms (Rothenbacher and Brenner 2003). The occurrence of antibodies against gastroparietal cells of the stomach has been reported as high as $12 \%$ (Šterzl et al. 1996).

Autoimmune gastritis and its sequel gastric atrophy predispose the subject to, albeit weakly, development of adenocarcinoma in the stomach, however, a strong association with infectious gastritis was recognized well before the identification of $H$. pylori as the cause of gastritis in this context.

As the most readily demonstrable serologic marker of autoimmune gastritis serve the gastric parietal cell autoantibodies, which, in diagnostic laboratories, are usually detected by immunofluorescence on a frozen section of murine stomach. They are highly associated with histologic evidence of gastritis and particularly with fundal gastritis (Whittingham and Mackay 2002).

The aim of this study was to evaluate the relationships between thyroid and gastric autoimmunity and H. pylori infection on a large sample of Czech population by monitoring the autoantibodies against thyroglobulin (anti-Tg) and thyroid peroxidase (anti-TPO) and gastric parietal cell (anti-GPC, representing thyrogastric syndrome) in correlation with antibodies against Helicobacter pylori (anti-H. pylori) of classes IgG and IgA.

\section{Methods}

Subjects were selected from the population of the regions of Jablonec nad Nisou (Zamrazil et al. 2004), Př́bram and Ždár nad Sázavou in the years 2004-2006. $(\mathrm{n}=1621$, mean age \pm SD: $27.7 \pm 18.7$; men: $n=700$, $25.2 \pm 18.8$ years, women: $n=921,29.5 \pm 18.4$ years). The ethical prerequisite of informed consent of the people involved was met.

Antibodies against H. pylori $\mathrm{IgG}$ and H. pylori

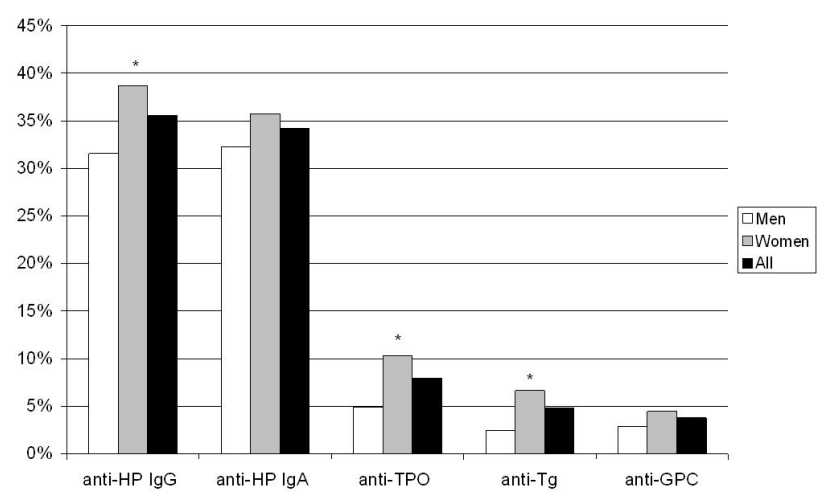

Fig. 1. The occurrence of anti- $H$. pylori, anti-TPO, anti-Tg and anti-GPC in the selected population. anti-HP IgG - anti $H$. pylor IgG; anti-HP IgA - anti-H. pylori IgA; $*$ significant difference $(p<0.05)$.

IgA were determined using ELISA kits Pyloriset EIA-G III Pyloriset EIA-A III from Orion Diagnostica. Results were considered positive when higher than $20 \mathrm{U} / \mathrm{ml}$. Anti-Tg and anti-TPO autoantibodies were determined using ELISA kits AESKULISA a-Tg (results were considered borderline when higher than $125 \mathrm{IU} / \mathrm{ml}$ and positive when higher than $150 \mathrm{IU} / \mathrm{ml}$ ) and AESKULISA a-TPO (results were considered borderline when higher than $25 \mathrm{IU} / \mathrm{ml}$ and positive when higher than $50 \mathrm{IU} / \mathrm{ml}$ ) (AESKU.DIAGNOSTICS, Wendelsheim, Germany). Autoantibodies against gastric parietal cells were determined using the indirect fluorescence kit Rat Kidney, Stomach IFA Kit from The Binding Site Limited (Birmingham, UK).

People were considered positive to Helicobacter pylori when having positive at least one antibody. People were considered as showing signs of thyroid autoimmunity, when positive at least to one of the anti- $\mathrm{Tg}$ and anti-TPO autoantibodies.

Differences in the prevalences were evaluated using two-sided Fisher's exact test using $\mathrm{R}$ statistical package ( $\mathrm{R}$ Development Core Team 2007).

\section{Results}

\section{Occurrence of antibodies and autoantibodies}

The occurrence of anti-H. pylori IgG was $35.6 \%$, anti-H. pylori IgA $34.2 \%$, anti-TPO $8.0 \%$, anti-Tg $4.8 \%$ and anti-GPC $3.8 \%$ (Fig. 1). Women showed higher occurrence of anti-H. pylori IgG, anti-Tg and anti-TPO and lower occurrence of anti-GPC than men (Fig. 1). Persons older than 18 years showed higher occurrence of anti-H. pylori and of all monitored 


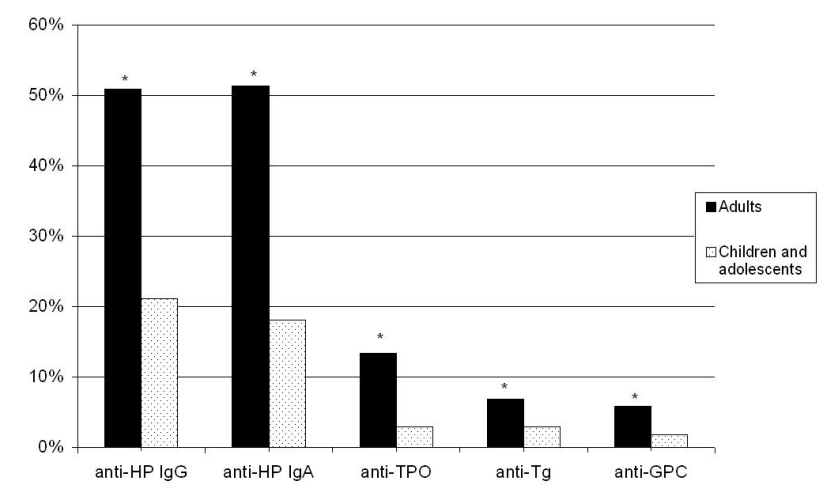

Fig. 2. Differences in the occurrence of anti- $H$. pylori, anti-TPO, anti-Tg and anti-GPC in the selected population. anti-HP IgG anti $H$. pylori IgG; anti-HP IgA - anti- $H$. pylori IgA; adults persons of age 18 years and older, children and adolescents persons under 18 years of age; * significant difference $(p<0.05)$.

autoantibodies (Fig. 2, p<0.001). The age dependence of anti-H. pylori and of all monitored autoantibodies is shown in Figure 3.

Relationship of the occurrence of autoantibodies on H. pylori seropositivity

In $H$. pylori seropositive persons as compared to seronegative irrespective of age and sex higher occurrence of anti-TPO (10.4\% vs. $5.8 \%, \mathrm{p}=0.001)$ and anti-GPC (6.1 \% vs. $1.7 \%, \mathrm{p}<0.001)$ was found. Differences in anti-TPO occurrence were significant in men $(7.0 \%$ vs. $3.3 \%, p=0.03)$ and also in women ( $12.7 \%$ vs. $8.0 \%, p=0.02)$, anti-GPC occurrence only in women $(7.2 \%$ vs. $1.7 \%, \mathrm{p}<0.001)$. In persons up to 18 years of age, irrespective of sex, a difference showed up in anti-TPO (4.7\% vs. $2.1 \%, \mathrm{p}<0.05)$ and anti-GPC occurrence ( $3.9 \%$ vs. $0.9 \%, p=0.004$ ), with respect to sex only in young females a difference in the anti-GPC occurrence (4.6 \% vs. $0.7 \%, \mathrm{p}<0.02)$ appeared. In persons older than 18 years, irrespective of sex, a difference in anti-GPC occurrence (7.2\% vs. $3.5 \%$, $\mathrm{p}=0.04)$ appeared, with respect to sex however, only in women $(8.3 \%$ vs. $3.2 \%, \mathrm{p}=0.02)$ (Table 1$)$.

Relationship of anti-GPC and anti-H. pylori occurrence on the positivity of anti-thyroid autoantibodies

In persons with positive autoantibodies against any of the thyroid antigens higher anti-H. pylori IgG (44.4\% vs. $34.5 \%$, p=0.01) and $\operatorname{IgA}(43.9 \%$ vs. $33.0 \%$, $\mathrm{p}=0.005)$ and anti-GPC (7.2 \% vs. $3.3 \%, \mathrm{p}=0.02)$ were found as compared to autoantibody negative persons irrespective of age and sex. With respect to sex differences were found for anti-H. pylori $\operatorname{IgA}$ in women

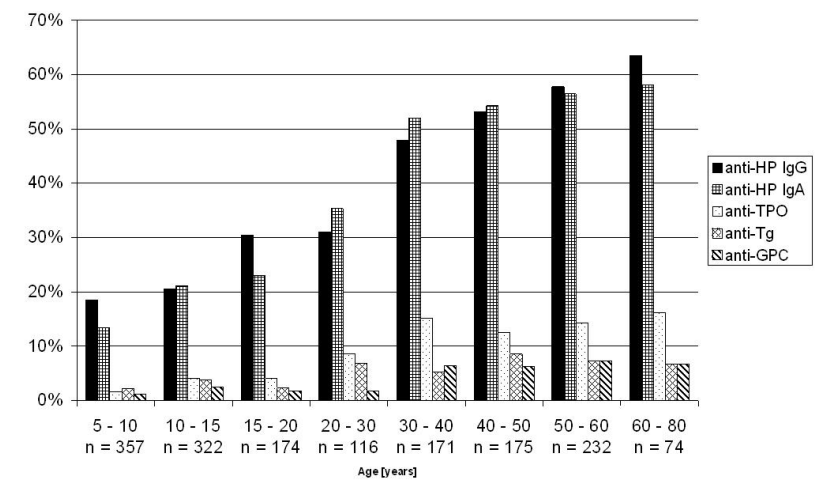

Fig. 3. Age dependence of the occurrence of anti- $H$. pylori, anti-TPO, anti-Tg and anti-GPC in the selected population. anti-HP IgG = anti $H$. pylori IgG; anti-HP IgA = anti-H. pylori IgA.

(44.4\% vs. $34.3 \%, \mathrm{p}=0.03)$ and for anti-GPC in men ( $8.5 \%$ vs. $2.5 \%, \mathrm{p}=0.04)$. These differences were not confirmed in the age group under 18 years, in the group older than 18 years only the difference for anti-GPC in men was confirmed (Table 2).

Relationship of anti-GPC and anti-H. pylori occurrence on the positivity of anti-thyroid autoantibodies

In persons with positive autoantibodies against any of the thyroid antigens higher anti-H. pylori $\mathrm{IgG}$ (44.4\% vs. $34.5 \%, \mathrm{p}=0.01)$ and $\operatorname{IgA}(43.9 \%$ vs. $33.0 \%$, $\mathrm{p}=0.005)$ and anti-GPC (7.2\% vs. $3.3 \%, \mathrm{p}=0.02)$ were found as compared to autoantibody negative persons irrespective of age and sex. With respect to sex differences were found for anti-H. pylori $\operatorname{IgA}$ in women (44.4\% vs. $34.3 \%, \mathrm{p}=0.03)$ and for anti-GPC in men ( $8.5 \%$ vs. $2.5 \%, p=0.04)$. These differences were not confirmed in the age group under 18 years, in the group older than 18 years only the difference for anti-GPC in men was confirmed (Table 2).

\section{Discussion}

Infection with $H$. pylori in connection to autoimmune thyroiditis has been studied by many researchers (Bertalot et al. 2004, de Luis et al. 1998, Figura et al. 1999, Raymond et al. 2000). The putative mechanism to explain how $H$. pylori infection in the stomach can pathogenically influence remote organs is the induction of an autoimmune reaction by molecular mimicry (Moran et al. 1996, Negrini et al. 1996). Antigens involved in this cross-reaction were partially identified as Lewis antigens of blood groups (Appelmelk et al. 1996, Moran 1996). In addition, eradication of 
Table 1. Significant differences between $H$. pylori negative and $H$. pylori positive persons.

\begin{tabular}{lccccc}
\hline Age group & Gender & Antibody & H. pylori positive & H. pylori negative & p-value \\
\hline All & All & anti-TPO & $10.4 \%$ & $5.8 \%$ & 0.001 \\
All & All & anti-GPC & $6.1 \%$ & $1.7 \%$ & $<0.001$ \\
All & M & anti-TPO & $7.0 \%$ & $3.3 \%$ & 0.032 \\
All & F & anti-TPO & $12.7 \%$ & $8.0 \%$ & 0.022 \\
Children and adolescents & F & anti-GPC & $7.2 \%$ & $1.7 \%$ & $<0.001$ \\
Children and adolescents & All & anti-TPO & $4.7 \%$ & $2.1 \%$ & 0.046 \\
Children and adolescents & All & anti-GPC & $3.9 \%$ & $0.9 \%$ & 0.004 \\
Adults & F & anti-GPC & $4.6 \%$ & $0.7 \%$ & 0.015 \\
Adults & All & anti-GPC & $7.2 \%$ & $3.5 \%$ & 0.039 \\
\hline
\end{tabular}

Children and adolescents - persons under 18 years of age. Adults - persons older than 18 years.

Table 2. Significant differences between anti-thyroid autoantibody negative and anti-thyroid autoantibody positive persons.

\begin{tabular}{lccccc}
\hline Age group & Gender & Antibody & Thyroid ab* positive & Thyroid ab* negative & p-value \\
\hline \multirow{2}{*}{ All } & All & anti-H. pylori IgG & $44.4 \%$ & $34.5 \%$ & 0.010 \\
All & All & anti-H. pylori IgA & $43.9 \%$ & $33.0 \%$ & 0.005 \\
All & All & anti-GPC & $7.2 \%$ & $3.3 \%$ & 0.019 \\
All & F & anti-H. pylori IgA & $44.4 \%$ & $34.3 \%$ & 0.031 \\
All & M & anti-GPC & $8.5 \%$ & $2.5 \%$ & 0.039 \\
Adults & M & anti-GPC & $12.9 \%$ & $3.7 \%$ & 0.046 \\
\hline
\end{tabular}

Children and adolescents - persons under 18 years of age. Adults - persons older than 18 years. *autoantibody.

H. pylori infection reduced the symptoms of autoimmune process, i.e., caused a decrease in the levels of antithyroid autoantibodies (Bertalot et al. 2004). Several authors described a relationship between $H$. pylori infection and gastric autoimunity (D'Elios et al. 2004, Presotto et al. 2003).

Detection of antibodies against CagA antigen of H. pylori has not been subject of this study, however, in a previous study (Šterzl et al. 2006), we could not show a significantly higher prevalence of antibodies to CagA in patients with AT as compared with controls, in contrast to another study (Figura et al. 1999).

Our study of 1621 people is, up to now, the largest study of $H$. pylori seropositivity reported in the Czech Republic. The population sample was selected from different regions of the Czech Republic during 2004-2006. In our study, the prevalence is somewhat higher than in other developed countries (anti-H. pylori IgG 35.6 \%, IgA $34.2 \%$.) (Goodman and Correa 1995,
Pounder and Ng 1995). Bureš et al. (2006) showed similar results in the Czech Republic in spite of using a different method, namely the urease breath test. Roberts et al. (2000) showed that the sensitivity and specifity of serological tests is generally lower than those of breath tests. In accordance with other authors (Sorberg et al. 2003, Robertson et al. 2003) we found an age dependence of the occurrence of $H$. pylori seropositivity increasing with age. The observed occurrence of anti-TPO (8.0\%) and anti-Tg $(4.8 \%)$ in the population under study, without regard to age or gender was slightly lower, as compared with other authors (Tajtaková et al. 2000, Prummel and Wiersinga 2005, Vanderpump et al. 1995).

In accordance with other authors (Vanderpump et al. 1995, Hawkins et al. 1980, Prentice et al. 1990) the occurrence of anti-Tg and anti-TPO autoantibodies increased with age - anti-Tg (6.8\% in older vs. $2.9 \%$ in younger, $\mathrm{p}<0.001)$, anti-TPO (13.3\% vs. $2.9 \%$, p<0.001) and certain results were more frequent in women, 
specifically anti-Tg ( $6.6 \%$ vs. $2.4 \%$, p $<0.001)$, and antiTPO (10.3\% vs. $4.9 \%, \mathrm{p}<0.001)$.

Several authors point to the relationship of autoimmune thyroiditis and Helicobacter pylori infection (de Luis et al. 1998, Figura et al. 1999). Helicobacter pylori might be the possible etiological factor for autoimmune thyroiditis development. A significant interaction between HLA-DRB $1 * 0301$ and $H$. pylori infection was present in AT patients and not controls (Larizza et al. 2006).

In the group of the $H$. pylori seropositive subjects, higher occurrence of anti-TPO and anti-GPC was found. On the other hand, in people with laboratory signs of thyroid autoimmunity, a higher occurrence of anti-H. pylori antibodies, and also a higher occurrence of anti-GPC autoantibodies was observed. When taking into account gender and age, only differences in anti-GPC in men, especially of higher age, persisted.

The occurrence of anti-GPC autoantibodies in the selected population was $3.8 \%$. No previous studies were found regarding the anti-GPC prevalence in the general, randomly selected population. All studies describe the occurrence of anti-GPC in various pathological states (Carmel 1992, Annibale et al. 2005, De Block et al. 2003). The occurrence of anti-GPC was not age or gender dependent. Results of this study suggest a possible relationship between anti GPC and the time course of Helicobacter pylori infection - the occurrence of anti-GPC was higher in $H$. pylori positive people $(6.1 \%$ vs. $1.7 \%, \mathrm{p}<0.001)$ and also in people with laboratory signs of autoimmune thyroiditis $(7.2 \%$ vs. $3.3 \%, \mathrm{p}=0.02)$. H. pylori infection can induce gastric autoimmunity, since of the bacteria leads to the production of antibodies cross-reacting with human gastric mucosa (Appelmelk et al. 1998, Negrini et al. 1991). The gastric mucosal pathogen Helicobacter pylori induces autoantibodies against the gastric proton pump $\mathrm{H}^{+}, \mathrm{K}^{+}$-ATPase in $20-30 \%$ of infected patients. The presence of these autoantibodies is associated with severity of gastritis (D'Elios et al. 2004). Our results suggest that gastric autoimmunity caused by $H$. pylori could also induce thyroid autoimmunity.

To conclude, we would like to point out that this study of a sample of the Czech population showed the occurrence of $H$. pylori in the same rates as in other developed countries. A slightly lower occurrence of seropositive anti-TPO and anti-Tg autoantibodies was found. Further, the supposed links were confirmed between anti-TPO autoantibodies and anti-GPC autoantibodies, which suggests the involvement of thyrogastric syndrome, i.e. autoimmune polyglandular syndrome type III on one hand and $H$. pylori seropositivity on the other, as a link between gastric and thyroid autoimmunity.

\section{Conflict of Interest}

There is no conflict of interest.

\section{Acknowledgements}

This work was supported by grants VZ MSM 0021620812 of the Ministry of Education and Youth, Czech Republic and IGA MZ ČR NR/9414-3 of the Internal Grant Agency of the Ministry of Health, Czech Republic.

\section{References}

ANNIBALE B, LAHNER E, NEGRINI R, BACCINI F, BORDI C, MONARCA B, DELLE FAVE G: Lack of specific association between gastric autoimmunity hallmarks and clinical presentations of atrophic body gastritis. World J Gastroenterol 11: 5351-5357, 2005.

APPELMELK BJ, SIMOONS-SMIT I, NEGRINI R, MORAN AP, ASPINALL GO, FORTE JG, DE VRIES T, QUAN $\mathrm{H}$, VERBOOM T, MAASKANT JJ, GHIARA P, KUIPERS EJ, BLOEMENA E, TADEMA TM, TOWNSEND RR, TYAGARAJAN K, CROTHERS JM, JR., MONTEIRO MA, SAVIO A, DE GRAAFF J: Potential role of molecular mimicry between Helicobacter pylori lipopolysaccharide and host Lewis blood group antigens in autoimmunity. Infect Immun 64: 2031-2040, 1996.

APPELMELK BJ, FALLER G, CLAEYS D, KIRCHNER T, VANDENBROUCKE-GRAULS CM: Bugs on trial: the case of Helicobacter pylori and autoimmunity. Immunol Today 19: 296-299, 1998.

BARDHAN PK: Epidemiological features of Helicobacter pylori infection in developing countries. Clin Infect Dis 25: 973-978, 1997.

BECH K, LARSEN JH, HANSEN JM, NERUP J: Letter: Yersinia enterocolitica infection and thyroid disorders. Lancet 2: 951-952, 1974. 
BECH K, NERUP J, LARSEN JH: Yersinia enterocolitica infection and thyroid diseases. Acta Endocrinol (Copenh) 84: 87-92, 1977.

BERTALOT G, MONTRESOR G, TAMPIERI M, SPASIANO A, PEDRONI M, MILANESI B, FAVRET M, MANCA N, NEGRINI R: Decrease in thyroid autoantibodies after eradication of Helicobacter pylori infection. Clin Endocrinol (Oxf) 61: 650-652, 2004.

BUREŠ J, KOPÁČOVÁ M, KOUPIL I, VOŘÍŠEK V, REJCHRT S, BERÁNEK M, SEIFERT B, POZLER O, ŽIVNÝ P, DOUDA T, KOLESÁROVÁ M, PINTER M, PALIČKA V, HOLČÍK J: Epidemiology of Helicobacter pylori infection in the Czech Republic. Helicobacter 11: 56-65, 2006.

CARMEL R: Reassessment of the relative prevalences of antibodies to gastric parietal cell and to intrinsic factor in patients with pernicious anaemia: influence of patient age and race. Clin Exp Immunol 89: 74-77, 1992.

D'ELIOS MM, APPELMELK BJ, AMEDEI A, BERGMAN MP, DEL PRETE G: Gastric autoimmunity: the role of Helicobacter pylori and molecular mimicry. Trends Mol Med 10: 316-323, 2004.

De BLOCK CE, De LEEUW IH, BOGERS JJ, PELCKMANS PA, IEVEN MM, VAN MARCK EA, VAN ACKER KL, VAN GAAL LF: Autoimmune gastropathy in type 1 diabetic patients with parietal cell antibodies: histological and clinical findings. Diabetes Care 26: 82-88, 2003.

De LUiS DA, VAREla C, De la CALLE H, CANTON R, De ARGILA CM, SAN ROMAN AL, BOIXEDA D: Helicobacter pylori infection is markedly increased in patients with autoimmune atrophic thyroiditis. $J$ Clin Gastroenterol 26: 259-263, 1998.

FIGURA N, DI CAIRANO G, LORE F, GUARINO E, GRAGNOLI A, CATALDO D, GIANNACE R, VAIRA D, BIANCIARDI L, KRISTODHULLU S, LENZI C, TORRICELLI V, ORLANDINI G, GENNARI C: The infection by Helicobacter pylori strains expressing CagA is highly prevalent in women with autoimmune thyroid disorders. J Physiol Pharmacol 50: 817-826, 1999.

FRENCK RW, JR., CLEMENS J: Helicobacter in the developing world. Microbes Infect 5: 705-713, 2003.

GOODMAN KJ, CORREA P: The transmission of Helicobacter pylori. A critical review of the evidence. Int $J$ Epidemiol 24: 875-887, 1995.

HAWKINS BR, CHEAH PS, DAWKINS RL, WHITTINGHAM S, BURGER HG, PATEL Y, MACKAY IR, WELBORN TA: Diagnostic significance of thyroid microsomal antibodies in randomly selected population. Lancet 2: 1057-1059, 1980.

HRDÁ P, ŠTERZL I, MATUCHA P, KORIOTH F, KROMMINGA A: HLA antigen expression in autoimmune endocrinopathies. Physiol Res 53: 191-197, 2004.

LARIZZA D, CALCATERRA V, MARTINETTI M, NEGRINI R, DE SILVESTRI A, CISTERNINO M, IANNONE AM, SOLCIA E: Helicobacter pylori infection and autoimmune thyroid disease in young patients: the disadvantage of carrying the human leukocyte antigen-DRB1*0301 allele. J Clin Endocrinol Metab 91: 176179, 2006.

LAURETI S, DE BELLIS A, MUCCITELLI VI, CALCINARO F, BIZZARRO A, ROSSI R, BELLASTELLA A, SANTEUSANIO F, FALORNI A: Levels of adrenocortical autoantibodies correlate with the degree of adrenal dysfunction in subjects with preclinical Addison's disease. J Clin Endocrinol Metab 83: 3507-3511, 1998.

MORAN AP: Helicobacter pylori expresses Lewis X. Helicobacter 1: 190-191, 1996.

MORAN AP, PRENDERGAST MM, APPELMELK BJ: Molecular mimicry of host structures by bacterial lipopolysaccharides and its contribution to disease. FEMS Immunol Med Microbiol 16: 105-115, 1996.

MUIR A, SCHATZ DA, MACLAREN NK: Polyglandular failure syndromes. In: Endocrinology. LJ DEGROOT, M BESSER, HG BURGER (eds), Saunders, Philadelphia, 1995, pp 3013-3022.

NEGRINI R, LISATO L, ZANELLA I, CAVAZZINI L, GULLINI S, VILLANACCI V, POIESI C, ALBERTINI A, GHIELMI S: Helicobacter pylori infection induces antibodies cross-reacting with human gastric mucosa. Gastroenterology 101: 437-445, 1991.

NEGRINI R, SAVIO A, POIESI C, APPELMELK BJ, BUFFOLI F, PATERLINI A, CESARI P, GRAFFEO M, VAIRA D, FRANZIN G: Antigenic mimicry between Helicobacter pylori and gastric mucosa in the pathogenesis of body atrophic gastritis. Gastroenterology 111: 655-665, 1996.

POUNDER RE, NG D: The prevalence of Helicobacter pylori infection in different countries. Aliment Pharmacol Ther 9 (Suppl 2): 33-39, 1995. 
PRENTICE LM, PHILLIPS DI, SARSERO D, BEEVER K, MCLACHLAN SM, SMITH BR: Geographical distribution of subclinical autoimmune thyroid disease in Britain: a study using highly sensitive direct assays for autoantibodies to thyroglobulin and thyroid peroxidase. Acta Endocrinol (Copenh) 123: 493-498, 1990.

PRESOTTO F, SABINI B, CECCHETTO A, PLEBANI M, DE LAZZARI F, PEDINI B, BETTERLE C: Helicobacter pylori infection and gastric autoimmune diseases: is there a link? Helicobacter 8: 578-584, 2003.

PRUMMEL MF, WIERSINGA WM: Thyroid peroxidase autoantibodies in euthyroid subjects. Best Pract Res Clin Endocrinol Metab 19: 1-15, 2005.

R DEVELOPMENT CORE TEAM: R: A Language and Environment for Statistical Computing. R Foundation for Statistical Computing, Vienna, Austria, 2007.

RAYMOND J, SAUVESTRE C, KALACH N, BERGERET M, DUPONT C: Immunoblotting and serology for diagnosis of Helicobacter pylori infection in children. Pediatr Infect Dis J 19: 118-121, 2000.

ROBERTS AP, CHILDS SM, RUBIN G, DE WIT NJ: Tests for Helicobacter pylori infection: a critical appraisal from primary care. Fam Pract 17 (Suppl 2): S12-S20, 2000.

ROBERTSON MS, CADE JF, SAVOIA HF, CLANCY RL: Helicobacter pylori infection in the Australian community: current prevalence and lack of association with ABO blood groups. Intern Med J 33: 163-167, 2003.

ROTHENBACHER D, BRENNER H: Burden of Helicobacter pylori and H. pylori-related diseases in developed countries: recent developments and future implications. Microbes Infect 5: 693-703, 2003.

SORBERG M, NYREN O, GRANSTROM M: Unexpected decrease with age of Helicobacter pylori seroprevalence among Swedish blood donors. J Clin Microbiol 41: 4038-4042, 2003.

ŠTERZL I, VAVREJNOVÁ V, MATUCHA P: Extra-thyroid autoantibodies in autoimmune thyroiditis [In Czech]. Vnitr Lek 42: 733-737, 1996.

ŠTERZL I, HRDÁ P, POTUŽNIKOVÁ B, MATUCHA P, HANA V, ZAMRAZIL V: Autoimmune thyroiditis and Helicobacter pylori - is there connection? Neuroendocrinol Lett 27: 41-45, 2006.

SUERBAUM S, MICHETTI P: Helicobacter pylori infection. N Engl J Med 347: 1175-1186, 2002.

TAJTAKOVÁ M, LANGER P, FODOR G, HANZEN E, PUTZ Z, KOŠŤÁLOVÁ L, MICHÁLEK J, KREZE A, KLIMEŠ I, ŠEBÖKOVÁ E: Epidemiological profile of thyroid volume and disorders in Slovakia [In Slovak]. Vnitr Lek 46: 756-763, 2000.

TODD JA, ACHA-ORBEA H, BELL JI, CHAO N, FRONEK Z, JACOB CO, MCDERMOTT M, SINHA AA, TIMMERMAN L, STEINMAN L, MCDEVITT HO: A molecular basis for MHC class II-associated autoimmunity. Science 240: 1003-1009, 1988.

TSANG KW, LAM SK: Helicobacter pylori and extra-digestive diseases. J Gastroenterol Hepatol 14: 844-850, 1999.

VANDERPUMP MP, TUNBRIDGE WM, FRENCH JM, APPLETON D, BATES D, CLARK F, GRIMLEY EVANS J, HASAN DM, RODGERS H, TUNBRIDGE F, AL. E: The incidence of thyroid disorders in the community: a twenty-year follow-up of the Whickham Survey. Clin Endocrinol (Oxf) 43: 55-68, 1995.

WHITTINGHAM S, MACKAY IR: Autoimmune Gastritis. In: Immunologically Mediated Endocrine Diseases. GILL DG, HARMON JT, MACLAREN NK (eds), Lippincott, Williams \& Wilkins, Philadelphia, 2002, pp 453-473.

ZAMRAZIL V, BÍLEK R, ČEǨOVSKÁ J, DELANGE F: The elimination of iodine deficiency in the Czech Republic: the steps toward success. Thyroid 14: 49-56, 2004. 